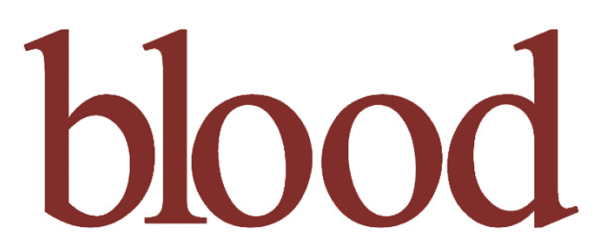

2008 112: 2463-2473

Prepublished online Jun 25, 2008;

doi:10.1182/blood-2007-09-115477

\title{
Oncogenic Kit controls neoplastic mast cell growth through a Stat5/PI3-kinase signaling cascade
}

Noria Harir, Cédric Boudot, Katrin Friedbichler, Karoline Sonneck, Rudin Kondo, Séverine Martin-Lannerée, Lukas Kenner, Marc Kerenyi, Saliha Yahiaoui, Valérie Gouilleux-Gruart, Jean

Gondry, Laurence Bénit, Isabelle Dusanter-Fourt, Kaïss Lassoued, Peter Valent, Richard Moriggl and Fabrice Gouilleux

Updated information and services can be found at:

http://bloodjournal.hematologylibrary.org/cgi/content/full/112/6/2463

Articles on similar topics may be found in the following Blood collections:

Neoplasia (4224 articles)

Information about reproducing this article in parts or in its entirety may be found online at:

http://bloodjournal.hematologylibrary.org/misc/rights.dtl\#repub_requests

Information about ordering reprints may be found online at:

http://bloodjournal.hematologylibrary.org/misc/rights.dtl\#reprints

Information about subscriptions and ASH membership may be found online at:

http://bloodjournal.hematologylibrary.org/subscriptions/index.dtl

Blood (print ISSN 0006-4971, online ISSN 1528-0020), is published semimonthly by the American Society of Hematology, 1900 M St, NW, Suite 200, Washington DC 20036.

Copyright 2007 by The American Society of Hematology; all rights reserved.

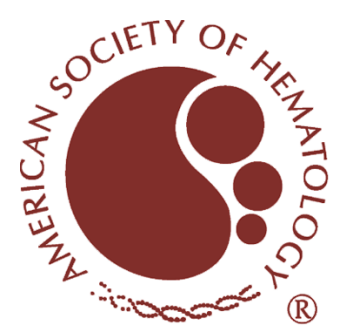




\title{
Oncogenic Kit controls neoplastic mast cell growth through a Stat5/PI3-kinase signaling cascade
}

\author{
*Noria Harir, ${ }^{1}$ 'Cédric Boudot, ${ }^{1}$ Katrin Friedbichler, ${ }^{2}$ Karoline Sonneck, ${ }^{3}$ Rudin Kondo, ${ }^{3}$ Séverine Martin-Lannerée, ${ }^{4,5}$ \\ Lukas Kenner, ${ }^{2,6}$ Marc Kerenyi, ${ }^{7}$ Saliha Yahiaoui, ${ }^{1}$ Valérie Gouilleux-Gruart, ${ }^{1}$ Jean Gondry, ${ }^{8}$ Laurence Bénit, $, 4,5$ \\ Isabelle Dusanter-Fourt, ${ }^{4,5}$ Kaïss Lassoued, ${ }^{1}$ Peter Valent, ${ }^{3}$ †Richard Moriggl, ${ }^{2}$ and †Fabrice Gouilleux ${ }^{1}$ \\ ${ }^{1}$ Inserm (EMI 351), Faculté de Médecine, Université de Picardie J. Verne, Amiens, France; '2udwig Boltzmann Institute for Cancer Research, Vienna, Austria; \\ ${ }^{3}$ Department of Internal Medicine I, Division of Hematology and Hemostaseology, Medical University of Vienna, Austria; ${ }^{4}$ Institut Cochin, Université Paris \\ Descartes, CNRS (UMR 8104), Paris, France; ${ }^{5}$ nserm U567, Paris, France; ${ }^{6}$ Department of Pathology, Medical University of Vienna, Austria; ${ }^{7}$ Max F. Perutz \\ Laboratories, Department of Medical Biochemistry, Division of Molecular Biology, Medical University of Vienna, Austria; and ${ }^{8}$ Centre Gynécologie-Obstétrique, \\ Centre Hospitalier Universitaire, Amiens, France
}

The D816V-mutated variant of Kit triggers multiple signaling pathways and is considered essential for malignant transformation in mast cell (MC) neoplasms. We here describe that constitutive activation of the Stat5-PI3K-Akt-cascade controls neoplastic MC development. Retrovirally transduced active Stat5 (CS5F) was found to trigger PI3K and Akt activation, and to transform murine bone marrow progenitors into tissue-infiltrating MCs. Primary neoplastic Kit D816V+ MCs in patients with mastocytosis also displayed activated Stat5, which was found to localize to the cytoplasm and to form a signaling complex with PI3K, with consecutive Akt activation. Finally, the knock-down of either Stat5 or Akt activity resulted in growth inhibition of neoplastic Kit D816V+ MCs. These data suggest that a downstream Stat5-PI3K-Akt signaling cascade is essential for Kit D816V-mediated growth and survival of neoplastic MCs. (Blood. 2008;112:2463-2473)

\section{Introduction}

Mast cells (MCs) are critical effector cells in innate and acquired immunity. ${ }^{1,2}$ Under various circumstances and pathologic conditions, MCs increase in number and accumulate in various tissues and organs. In many cases, reactive MC hyperplasia is found. ${ }^{1}$ However, MCs (MC progenitors) may also undergo neoplastic transformation., ${ }^{3,4}$ Disorders that lead to enhanced proliferation and/or accumulation of neoplastic MCs are well defined by WHO criteria. ${ }^{3-6}$

MCs are derived from pluripotent hematopoietic cells in the bone marrow and undergo terminal maturation in their ultimate tissue destinations under the influence of stem cell factor, also known as Kit ligand. ${ }^{7-9}$ Studies in MC-deficient mouse strains displaying mutations in the stem cell factor $(S C F)$ gene or the gene encoding the SCF receptor, $c$-Kit, as well as activating $c$-Kit mutations that are considered to represent major transforming hits in mastocytosis, underline the importance of SCF and Kit for MC development. ${ }^{10-16}$ Binding of SCF to Kit induces activation of various signaling molecules including phospholipase $\mathrm{C}$, the Src family tyrosine kinase, the scaffolding molecule Gab2, the MAP Kinases Erk1/2, the JAK tyrosine kinase, the Phosphatidyl-inositol 3-kinase (PI3K), and the Stat transcription factors. ${ }^{17-19}$ Lessons from gene deletion studies in mice have indicated that PI3K, Gab2, and Stat5 play a critical role in MC development and function, suggesting that these molecules may represent important downstream effectors of c-Kit signaling. ${ }^{20-22}$ Moreover, recent data have shown that Stat5 and Gab2 are also required for signaling via the high affinity $\operatorname{IgE}$ receptor $\mathrm{Fc} \in \mathrm{RI}$ that plays a critical role in $\mathrm{MC}$ function and allergic response. ${ }^{23,24}$
Besides their physiologic role in MCs, accumulating evidence suggests that persistent Stat5 and PI3K activation is frequently found in hematopoietic neoplasms and solid tumors. ${ }^{25,26}$ It has also been described that disease-related oncogenic tyrosine kinases like Tel-Jak2, Bcr-Abl, Tel-PDGFR $\beta$, mutated Kit or Flt3 receptors, and the Jak2 (V617F) mutant, detectable in most myeloproliferative disorders (MPDs), induce constitutive activation of Stat5, PI3K and its downstream effector, the serine threonine kinase Akt. ${ }^{27-35}$ Moreover, Stat5 proteins were found to be required for Tel-Jak2 - and Bcr-Abl-induced MPDs, ${ }^{36-38}$ and other studies have demonstrated the requirement of the PI3K/Akt pathway and Gab2 for Bcr-Abl-induced transformation. ${ }^{28,39}$ Direct evidence for the involvement of Stat5 in hematopoietic cell transformation came from the use of constitutively active Stat5 mutants Stat51*6 and $\mathrm{cS}^{\mathrm{F}}$ that are capable to induce an MPD and a multilineage leukemia in mice. ${ }^{36,40}$ We have recently shown that the leukemogenic effect of $\mathrm{cS}^{\mathrm{F}}$ is coupled with its capacity to activate the PI3K/Akt signaling pathway in the cytoplasm of neoplastic cells through complex formation with $\mathrm{p} 85$, the regulatory subunit of the PI3K, and Gab2. ${ }^{41,42}$

We asked in the current study whether persistent Stat5 and Akt signaling contribute to the transformation of MCs in mastocytosis. The results of our study show that constitutively activated Stat5 and the subsequent Akt-activation promote abnormal development of MCs in vivo and in vitro. In addition, we show that Stat5 and Akt are constitutively phosphorylated in neoplastic MCs isolated from patients with $\mathrm{KitD} 816 \mathrm{~V}^{+}$systemic mastocytosis, and that in these
Submitted September 28, 2007; accepted June 7, 2008. Prepublished online as Blood First Edition paper, June 25, 2008; DOI 10.1182/blood-2007-09-115477.

${ }^{\star}$ N.H. and C.B. contributed equally to this work.

†R.M. and F.G. contributed equally to this work.
The online version of this article contains a data supplement.

The publication costs of this article were defrayed in part by page charge payment. Therefore, and solely to indicate this fact, this article is hereby marked "advertisement" in accordance with 18 USC section 1734.

(C) 2008 by The American Society of Hematology 


\section{From www.bloodjournal.org at CNRS BiblioVie on March 12, 2009. For personal use only.}

cells, activated cytoplasmic Stat5 proteins associate with PI3K. Inhibition of Stat5 or Akt activity by shRNA or transducible, dominant-negative recombinant TAT fusion proteins of Stat5 or Akt were found to abrogate the growth of neoplastic MCs expressing the oncogenic KitD816V mutant. In contrast, transduction of a TAT fusion protein containing the $\mathrm{CS}^{\mathrm{F}}$ mutant promoted SCF-induced hematopoietic stem cell (HSC) expansion and MC development.

Collectively, these data suggest that activated cytoplasmic Stat5 is an important downstream effector molecule of oncogenic Kit kinase activation, and that Stat5 oncogenic properties in MCs may rely on the interaction with the PI3K/Akt kinase pathway.

\section{Methods}

\section{Animals, primary cell isolation, and cell culture}

Introduction of recombinant retroviruses carrying $\mathrm{cS}^{\mathrm{F}}$ and IRES-EGFP (green fluorescent protein) or the IRES-EGFP vector alone in murine BM cells and mice transplantation were done as previously described. ${ }^{40}$ Bone marrow was harvested from hind limbs of leukemic and control mice 6 weeks after transplantation. BM cells from leukemic mice $\left(\mathrm{cS}^{\mathrm{F}}\right.$ mice) were grown for 24 hours in RPMI 1640 with $10 \%$ fetal calf serum (FCS) and SCF (10 ng/mL; Valbiotech, Paris, France) while BM cells from control mice (GFPv mice) were grown in the same medium supplemented with IL-3 $(10 \mathrm{ng} / \mathrm{mL})$. The next day, $\mathrm{GFP}^{+}$cells were sorted by flow cytometry and cultured in medium for 6 weeks. All mouse experiments were done in accordance with the institutional policies of the Ludwig Boltzman Institute for Cancer Research.

\section{Human $\mathrm{CD} 4^{+}$cell isolation and cell culture}

Umbilical cord blood samples were collected from full-term deliveries after informed consent was obtained from donors in accordance with the Declaration of Helsinki. Cord blood was diluted with phosphate-buffered saline (PBS) supplemented with $5 \mathrm{mM}$ EDTA. Mononuclear cells were collected after standard separation on Ficoll gradient. Purification of human $\mathrm{CD}^{+}{ }^{+}$cells was performed with an immunomagnetic bead separation kit (MiniMACS; Miltenyi Biotec, Auburn, CA) according to the manufacturer's instructions. The purity of the enriched $\mathrm{CD} 34^{+}$cells was approximately 95\%. Cells were then cultured in RPMI medium supplemented with $10 \%$ FCS, $2 \mathrm{mM}$ L-glutamine, $10 \mathrm{IU}$ penicillin, $10 \mu \mathrm{g} / \mathrm{mL}$ streptomycin, and $10 \mathrm{ng} / \mathrm{mL}$ rhSCF (Valbiotech). The human mast cell leukemia (MCL) cell line HMC- $1^{43}$ was kindly provided by Dr Joseph H. Butterfield (Mayo Clinic, Rochester, MN). In this study, subclone HMC-1.2 carrying KIT D816V was analyzed. HMC-1 cells were cultured in Iscove medium supplemented with $10 \%$ FCS, $2 \mathrm{mM}$ L-glutamine, $10 \mathrm{IU}$ penicillin, and $10 \mu \mathrm{g} / \mathrm{mL}$ streptomycin.

\section{Patients}

Twenty patients with systemic mastocytosis (SM) and 3 control cases (normal bone marrow) were examined. Mastocytosis was diagnosed according to established criteria. ${ }^{3}$ In the SM group, 15 patients had indolent SM (ISM), 2 had smoldering SM (SSM), 2 had aggressive SM (ASM), and 1 had mast-cell leukemia (MCL). Data from these 15 patients are assembled in Table 1. Informed consent was obtained before bone marrow biopsies were taken. The study was approved by the institutional review board of the Medical University of Vienna and was conducted in accordance with the Declaration of Helsinki.

\section{Plasmids and reagents}

The coding regions of wtStat5a, $\mathrm{cS}^{\mathrm{F}}$ and dnStat5a (Stat5a $\Delta 749$ ), wtAkt and dnAkt (K179M) were amplified by PCR and cloned at the KpnI/EcoRI (Stat5) or NcoI/EcoRI sites (Akt) of the bacterial expression vector pTAT-HA. The LY294002 PI3K inhibitor and the calcium ionophore
A23187 were purchased from Sigma-Aldrich (St Louis, MO), and the multikinase inhibitor PKC412 that blocks the TK activity of wild-type and mutant Kit was purchased from LC Laboratories (Woburn, MA).

\section{Lentiviral vectors and transduction}

Sense and antisense oligonucleotides (5'-GGAGAACCTCGTGTTCCTG$3^{\prime}$ ) from the human Stat5a and Stat5b coding region were annealed and introduced in pSuper plasmid $3^{\prime}$ of the polIII $\mathrm{H} 1$ promoter. polIII $\mathrm{H} 1$ promoter-shRNA Stat5 DNA fragment was then subcloned in the pTRIP/ $\Delta \mathrm{U} 36 \mathrm{EF} 1 \alpha$ encoding the green fluorescent protein (GFP) lentiviral vector, as previously described. ${ }^{44}$ An shRNA directed against luciferase protein was used as control (Luc). Production of both shRNA-Stat 5 and shRNALuc lentiviral vectors was performed as previously described. ${ }^{44}$ HMC-1 cells $\left(10^{6} / \mathrm{mL}\right)$ were incubated with the lentiviral particles at a multiplicity of infection (MOI) of 10 for 24 hours and then intensively washed. Cells were then maintained in Iscove medium during 2 days and $\mathrm{GFP}^{+}$cells were next sorted by FACS and cultured in the same medium for 9 days.

\section{Purification of recombinant TAT-Stat5 and TAT-Akt proteins}

The TAT-Stat5 and TAT-Akt fusion proteins were produced and purified as previously described. ${ }^{42}$ A concentration of $10 \mu \mathrm{M}$ was routinely prepared for each individual TAT-Stat5 and TAT-Akt preparation.

\section{Flow cytometry analysis}

Expression of cell-surface molecules was analyzed by flow cytometry. Cells $\left(5 \times 10^{5}\right)$ were incubated for 30 minutes on ice in the dark with the following PE-conjugated monoclonal antibodies: anti-human or -mouse Fc $\in$ RI (eBioscience, San Diego, CA), anti-human or -mouse CD117 (BD Bioscience, San Jose, CA), anti-human CD34 and with isotype control PE-conjugated antibodies. After washes in PBS containing 3\% bovine serum albumin (BSA), and $0.1 \%$ sodium azide, expression of these antigens was analyzed by FACS (Coulter Epics Elite cytometer; Beckman Coulter, Fullerton, CA) and evaluated as the percentage of positive cells. For flow cytometric detection of intracellular P-Y-Stat5, HMC-1 cells were incubated in control medium or medium containing PKC412 $(1 \mu \mathrm{M})$ for 4 hours. Then, cells were fixed in formaldehyde (1.6\%), permeabilized by ice-cold methanol $\left(-20^{\circ} \mathrm{C}, 10\right.$ minutes), washed in PBS containing $0.1 \%$ BSA, and stained with an Alexa488-conjugated monoclonal antibody against P-Y-Stat5 (anti-phospho-Stat5(Y694):Alexa Fluor 488; BD Biosciences), or an isotype-matched control antibody (mIgG1-Alexa Fluor 488; BD Biosciences) for 15 minutes at room temperature (RT). Cells were then washed in PBS/0.1\% BSA and analyzed by FACS.

\section{Immunoprecipitation, Western blotting, and antibodies}

Cells were lysed in Laemmli buffer (0.0625 M, pH 6.8, SDS 2\%, $\beta$-mercaptoethanol $5 \%$, glycerol 10\%). Equal amounts of each protein sample were separated by electrophoresis on sodium dodecyl sulfate-polyacrylamide gel electrophoresis (SDS-PAGE) and blotted onto nitrocellulose membrane (Bio-Rad, Hercules, CA). Blots were incubated as indicated with antibodies raised against the following proteins: Stat5 (Transduction Laboratories, Lexington, KY), HA (Roche, Basel, Switzerland), P-Y ${ }^{694 / 699}-$ Stat5a/b, P-Ser ${ }^{473}$-Akt (Cell Signaling Technology, Danvers, MA), Akt (Santa Cruz Biotechnology, Santa Cruz, CA), p85 (Upstate Biotechnolgy, Lake Placid, $\mathrm{NY}$ ). Membranes were developed with the enhanced chemiluminescence (ECL) detection system (GE Healthcare, Little Chalfont, United Kingdom) using specific peroxidase-conjugated anti-IgG antibodies. Immunoprecipitation experiments and subcellular fractionation were performed as previously described. ${ }^{41,42}$

\section{Immunohistochemistry and immunocytochemistry}

Immunohistochemistry was performed on serial consecutive sections from paraffin-embedded, formalin-fixed tissues using the indirect immunoperoxidase staining technique as described. ${ }^{45,46}$ Either patient bone marrow biopsies or murine stomach mucosa and submucosa sections of $\mathrm{cS}^{\mathrm{F}}$ mice and GFPv mice were stained. Sections were pretreated in $10 \mathrm{mM}$ citrate 
buffer ( $\mathrm{pH}$ 6.0) either in a microwave oven ( $\alpha$-tryptase) or steamer (all others) before staining with antibodies. Endogenous peroxidase was blocked by $\mathrm{PBS} / \mathrm{H}_{2} \mathrm{O}_{2}$. Tissues were treated with avidin/biotin blocker (Vector Laboratories, Burlingame, CA) and Super Block (ID Labs, London, $\mathrm{ON})$ to block unspecific protein staining. Mouse-on-mouse blocking solution (Vector Laboratories) was applied on sections stained with mouse primary antibodies. For immunhistochemical analysis, sections were stained with anti-tryptase antibody G3 (1:500; Chemicon, Temecula, CA), anti-PY-Stat5a/b antibody AX-1 with or without blocking peptide (1:1000; Advantex Bioreagents, Conroe, TX), and anti-P-S ${ }^{473}$-Akt with or without blocking peptide (P-S-Akt, no. 3787, 1:100; Cell Signaling Technology) diluted in PBS pH 7.4/1\% BSA. G3 or AX-1 antibodies were applied for 1 hour at RT, anti-P-S-Akt for 20 hours at $4^{\circ} \mathrm{C}$. Subsequently, slides were washed and incubated with a biotinylated anti-polyvalent $\operatorname{IgG}$ (ID Labs) for 10 minutes at RT, washed and exposed to streptavidin-horseradish peroxidase complex for 10 minutes (ID Labs). AEC (Sigma) was used as chromogen. Slides were counterstained in Mayer Hemalaun and mounted in Aquatex. To display organotypic structures, tissue sections were stained with hematoxylin and eosin (H\&E). To control for cytoplasmic localization of P-Y-Stat5 staining, a different antigen retrieval protocol was used. A high $\mathrm{pH}$ retrieval buffer (Ventana Medical Systems, Tucson, AZ; $\mathrm{pH}=8.0$ ) was applied for 15 minutes at $95^{\circ} \mathrm{C}$. Sections were incubated with the AX1 antibody at a dilution of 1:500 for 1 hour at RT. Subsequent antibody reactivity was detected as described. Quantification of immunohistochemical stainings was performed with the HistoQuest analysis software (TissueGnostics, Vienna, Austria; www.tissuegnostics.com) using an average of 4 fields of view. The cutoff value for background staining was chosen using the forward/backward gating tool of the HistoQuest software. Images were captured with a PixeLINK camera and the corresponding acquisition software on a Zeiss Imager Z.1 (magnification, $\times 400$ ) at a color temperature of $1300 \mathrm{~K}$. For details on the quantification method, see Figure S3 (available on the Blood website; see the Supplemental Materials link at the top of the online article). For immunocytochemical analysis, cells were spun on cytospin slides before staining with the AX1 or P-S-Akt antibodies. Slides were counterstained with Mayer Hemalaun.

\section{Histochemical staining}

$\mathrm{cS}^{\mathrm{F}}$-BMMCs or human MCs were spun on cytospin slides, fixed with Carnoy fluid, and incubated for 15 minutes with toluidine blue. For the degranulation experiments, $\mathrm{cS}^{\mathrm{F}}$-BMMCs were incubated with or without $2 \mu \mathrm{g} / \mathrm{mL}$ mouse $\operatorname{IgE}$ overnight at $37^{\circ} \mathrm{C}$, washed, and incubated with $10 \mu \mathrm{g} / \mathrm{mL}$ of affinity-purified anti-mouse $\mathrm{Ig}(\mathrm{H}+\mathrm{L})$ for 30 minutes at $37^{\circ} \mathrm{C}$ before staining with toluidine blue.

\section{Results}

\section{Constitutive activation of Stat5 induces abnormal development of murine MCs in vivo and in vitro}

Retroviral transduction of $\mathrm{cS}^{\mathrm{F}}$ in murine bone marrow (BM) cells leads to development of multilineage leukemia within 4 weeks after transplantation in lethally irradiated wild-type recipient mice. ${ }^{40}$ Disease is obvious in the spleen, bone marrow, and liver, but we found that the stomach wall and colon are also strongly inflamed (Figure S1A) and infiltrated with tryptase-positive MCs in tissue sections, compared with control mice that underwent transplantation with GFPv BM cells (Figure 1). Staining with an anti-P-Y-Stat5 antibody showed that these MCs abundantly express phosphorylated Stat5. We also observed a higher number of tryptase-positive cells expressing P-Y-Stat5 in stomach and large bowel submucosa and mucosa tissues (Figure 1A and Figures S1B and S2). In addition to MC infiltrates, we also detected an infiltration of intestinal walls by inflammatory cells of lymphoid and myeloid origin. These cells were also found to express P-Y-Stat5. Transplantation of BM cells transduced with wtStat5a or
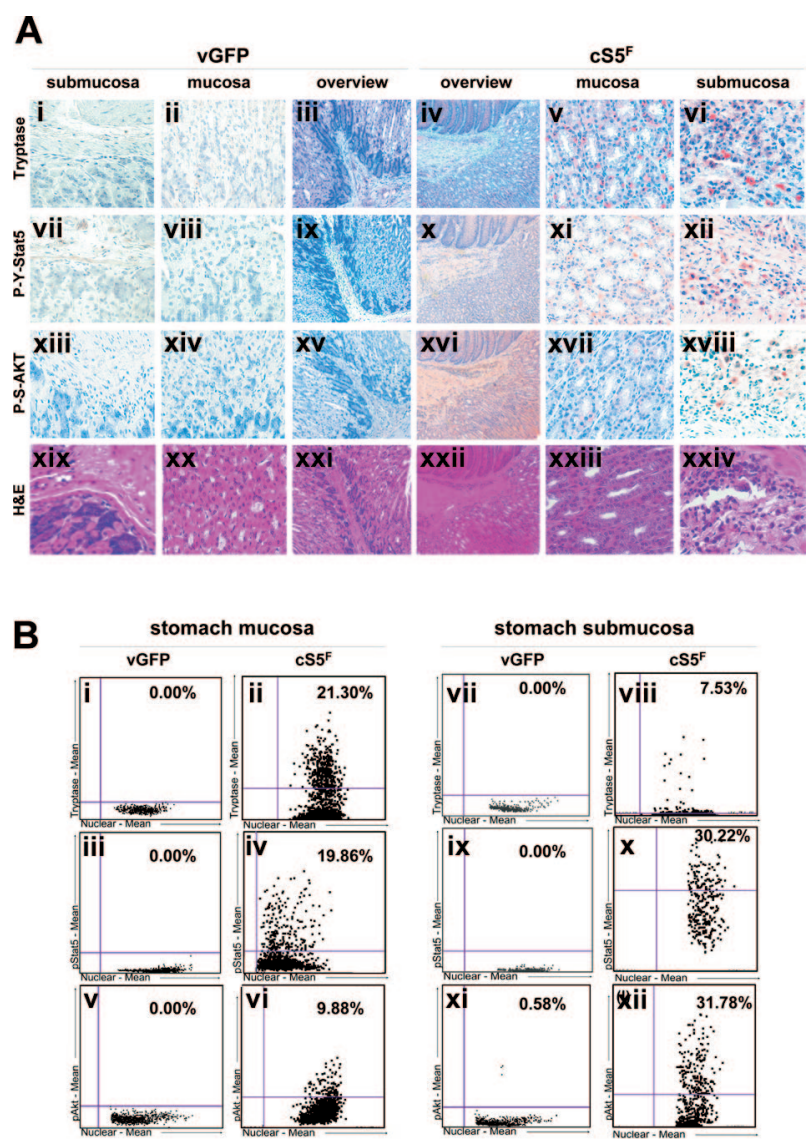

Figure 1. Constitutive activation of Stat5 induces mast cell hyperplasia and leukemic cell infiltrates in the gastrointestinal tract of $c S 5 F$ mice. (A) Immunohistochemical analysis of stomach walls of mice that underwent transplantation with $c S 5 F$ BM cells versus control mice that received GFPv BM cells $(n>6$ mice analyzed in each group and a representative example is shown). To detect neoplastic MCs, sections of the stomach mucosa and submucosa of $\mathrm{CS}^{\mathrm{F}}$ mice and control GFPv-mice were immunostained with an antitryptase antibody (i-vi). The presence of tyrosine ${ }^{694 / 695}$ phosphorylated Stat5 (P-Y-Stat5; vii-xii) and serine ${ }^{473}$ phosphorylated Akt (P-S-Akt; xiii-xviii) was analyzed with specific antibodies on consecutive tissue sections (original magnification, $\times 400$ ). An overview of each staining on consecutive sections is shown in the 2 panels labeled "Overview" (iii, iv, viiix, xv, xvi, xxi, xxii) for leukemia $\mathrm{CS}^{\mathrm{F}}$ and control GFPv mice (original magnifications, $\times 25$ and $\times 100$, respectively). H\&E staining is shown for organotypic structure comparison (xviiiixxiv). (B) Quantification of P-Y-Stat5, tryptase, and P-S-Akt stainings was performed on consecutive sections using HistoQuest analysis software (results shown in the scattergram plots are the mean of 4 fields of view for each staining). The cutoff values for background staining were chosen manually using the forward/backward gating tool of the HistoQuest software.

GFP-vector controls did not cause detectable leukocyte accumulations or MC infiltrates in the gastrointestinal tract.

Since oncogenic $\mathrm{cS}^{\mathrm{F}}$ proteins activate the PI3K/Akt pathway in bone marrow cells of leukemic $\mathrm{cS}^{\mathrm{F}}$ mice, ${ }^{42}$ the expression of the phosphorylated form of Akt in $\mathrm{cS}^{\mathrm{F}}$ stomach mucosa and submucosa tissues was analyzed (Figure 1A). Staining with anti-Pser473 Akt (P-S-Akt) antibody showed that $\mathrm{cS}^{\mathrm{F}}$-expressing $\mathrm{MCs}$ also express P-S-Akt. All data were confirmed by direct quantification of immunohistochemical stainings using the HistoQuest analysis software (Figure 1B, Figure S3). Furthermore, higher magnification of the $\mathrm{cS}^{\mathrm{F}}$ stomach submucosa section showed that $\mathrm{cS5}^{\mathrm{F}}$ is mainly detected in the cytoplasm, which is in line with our previous observation that constitutively active Stat5 has a predominant cytoplasmic localization in myeloid leukemias (Figure S2). The cytoplasmic localization of phosphorylated Stat5 was also confirmed with a different staining protocol with high $\mathrm{pH}$ antigen retrieval ${ }^{47}$ (Figure $\mathrm{S} 2$ ). 
A

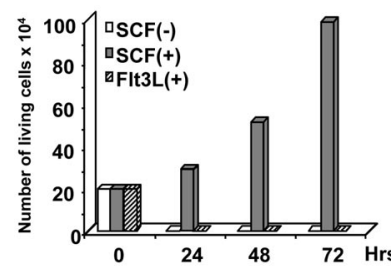

C

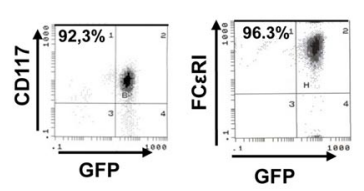

B

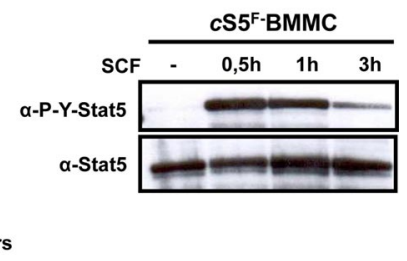

D

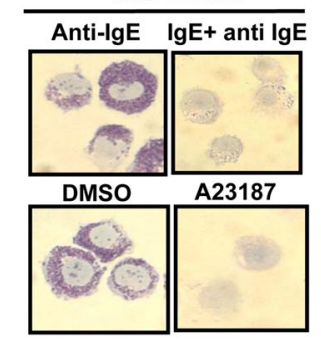

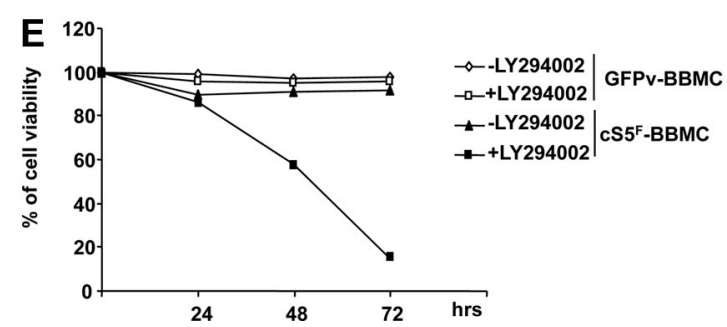

Figure 2. SCF-dependent activation of $\mathrm{CS}^{\mathrm{F}}$ promotes the development of murine mast cells in vitro. (A) Bone marrow (BM) cells from $\mathrm{CS}^{\mathrm{F}}$ mice were cultured in presence of SCF $(10 \mathrm{ng} / \mathrm{mL})$ or Flt3L $(10 \mathrm{ng} / \mathrm{mL})$ and viable cells were enumerated daily using the trypan blue dye exclusion method. (B) $\mathrm{CS}^{\mathrm{F}} \mathrm{F}-\mathrm{BM}$ cells were deprived of SCF for 3 hours and then restimulated for the indicated times. Cell extracts were prepared and analyzed by Western blot with anti-P-Y-Stat5 and anti-Stat5 antibodies. (C) Two-week-old $\mathrm{CS} 5 \mathrm{~F}$-BM cells grown in culture in presence of SCF were analyzed for expression of $\mathrm{FCERI}$ and $\mathrm{c}$-Kit by flow cytometry. (D) $\mathrm{CS} 5 \mathrm{~F}-\mathrm{BM}$-derived MCs (cS5F-BMMCs) were incubated with anti-IgE alone or/and $\operatorname{lgE}$. Alternatively, cells were treated with DMSO or A23187 and stained with toluidine blue. (E) CS5F-BMMCs and GFPv-BMMCs were treated or not with LY294002 (1 $\mu$ M) for 3 days and the percentage of viable cells was determined daily with the trypan blue dye exclusion assay. Results shown are representatives of 3 independent experiments.

\section{CS5 ${ }^{\mathrm{F}}$-induced proliferation of murine bone marrow cells and subsequent MC development is dependent on c-Kit receptor and PI3K activation}

MCs originally arise from hematopoietic progenitors in the bone marrow. ${ }^{7-9}$ We isolated GFP-positive bone marrow $\left(\mathrm{GFP}^{+} \mathrm{BM}\right)$ cells from different leukemic $\mathrm{cSr}^{\mathrm{F}}$ mice, 6 weeks after transplantation, to analyze the growth factor requirement of primary MCs in vitro. We first addressed whether activation of Kit is required to support $\mathrm{cS}^{\mathrm{F}}$-induced $\mathrm{BM}$ cell growth. $\mathrm{cS}^{\mathrm{F}} \mathrm{BM}$ cells were incubated at the indicated times with SCF or Flt3L (fetal liver tyrosine kinase-3 ligand) as control, and cell proliferation was determined (Figure 2A). Respective results showed that growth of $\mathrm{cS}^{\mathrm{F}} \mathrm{BM}$ cells required the continuous presence of SCF but not Flt3L. We also found that persistent phosphorylation of $\mathrm{cS}^{\mathrm{F}}$ is dependent on Kit activity in these primary leukemic cells (Figure 2B). To investigate whether expression of $\mathrm{CS}^{\mathrm{F}}$ could trigger $\mathrm{MC}$ differentiation in vitro, freshly isolated $\mathrm{GFP}^{+} \mathrm{BM}$ cells from cS5 ${ }^{\mathrm{F}}$ mice were grown in culture in the presence of SCF for 2 weeks. Expression of FceRI and c-Kit receptors were then analyzed by flow cytometry. Interestingly, $96 \%$ of $\mathrm{GFP}^{+}-\mathrm{cS}^{\mathrm{F}} \mathrm{BM}$ cells expressed FceRI and c-Kit surface receptors (Figure 2C). Almost

$100 \%$ of the cells contained toluidine blue-positive granules confirming that they were MCs (Figure 2D). It is well established that antigen-induced cross-linking of IgE bound to FceRI initiates $\mathrm{MC}$ activation and granule mediator release. ${ }^{48}$ We determined by toluidine blue staining whether $\mathrm{cS}^{\mathrm{F}}$-BM-derived $\mathrm{MCs}\left(\mathrm{cS} 5^{\mathrm{F}}\right.$ BMMCs) could be activated to release granule content by crosslinking IgE-receptors. Anti-IgE treatment of $\mathrm{cS}^{\mathrm{F}}-\mathrm{BMMCs}$ or treatment with the calcium ionophore A23187 induced degranulation of these cells (Figure 2D). These findings suggest that activation of $\mathrm{cS}^{\mathrm{F}}$ supports the development of functional MCs induced by SCF. These results are of interest, as development of normal murine $\mathrm{MCs}$ from their bone marrow progenitors is believed to require the presence of IL-3, not only $\mathrm{SCF}^{49}$ (Figures $\mathrm{S} 4 \mathrm{~A}, \mathrm{~B})$. Thus, our data suggest that expression of $\mathrm{cS} 5^{\mathrm{F}}$ bypasses the requirement of IL-3. Recent data on activation of the $\operatorname{IgE}$ receptor implied the involvement of an autocrine IL-3 loop, ${ }^{50}$ but we were not able to detect IL-3 mRNA or protein in our $\mathrm{cS}^{\mathrm{F}}$-BM-derived MC model (Figure S4C,D), excluding an IL-3 autocrine loop. In addition and in sharp contrast to $\mathrm{cS}^{5}$-BMMCs, we were not able to detect the phosphorylation of Stat5 upon stimulation with SCF in normal GFPv-BMMCs, indicating that persistent activation of $\mathrm{cS}^{\mathrm{F}}$ proteins via $\mathrm{SCF}$ stimulation can replace IL-3 as trigger of MC development (Figure S4E). We then asked whether activation of $\mathrm{PI} 3 \mathrm{~K}$ is also required for $\mathrm{cS}^{\mathrm{F}}$-induced $\mathrm{MC}$ growth and survival. $\mathrm{cS}^{5}$-BMMCs and control $\mathrm{GFPv-}$ BMMCs were left untreated or were treated with the PI3K inhibitor LY294002 (1 $\mu \mathrm{M})$ for 3 days, and the percentage of viable cells was then determined (Figure 2E). Growth of $\mathrm{cS}^{\mathrm{F}}$-BMMCs was completely abrogated by LY294002 at a concentration that did not affect GFPv-BMMCs proliferation, indicating that activation of the $\mathrm{PI} 3 \mathrm{~K} / \mathrm{Akt}$ pathway is necessary to sustain the proliferation and survival of $\mathrm{cS}^{\mathrm{F}}$-BMMCs.

\section{Stat5 and Akt are constitutively activated in neoplastic MCs in patients with mastocytosis}

Activating mutations of Kit are considered essential for the development of mastocytosis. . $14,15,51^{\text {To investigate whether masto- }}$ cytosis is also associated with constitutive Stat5 and Akt activation, immunohistochemical analysis was performed on bone marrow sections obtained from patients with $\mathrm{KitD} 16 \mathrm{~V}^{+}$systemic mastocytosis (SM) with anti-P-Y-Stat5, P-S-Akt, and antitryptase antibodies. In normal bone marrow, activated Stat5 was mainly detected in megakaryocytes and in some myeloid progenitor cells. By contrast, in the bone marrow in SM, numerous MC infiltrates were detected and more than $95 \%$ of all spindle-shaped cells (MCs) were found to be tryptase-positive cells and to express P-Y-Stat5 as determined by immunohistochemistry (same bone marrow and same patients) without any difference among patients (Figure 3A). In particular, in serial sections obtained from the same patients, more than $80 \%$ of the spindle-shaped cells (MCs) were found to react with the anti-P-Y-Stat5 antibody AX-1. Similarly, we found that neoplastic $\mathrm{MCs}$ in $\mathrm{SM}$ in the serial sections examined frequently express P-S-Akt (Figure 3B). Activated Stat5 and activated Akt were detectable in neoplastic MCs in all patients examined, including 5 with indolent systemic mastocytosis (ISM), 2 with smoldering SM (SSM), 1 with aggressive SM, and 1 patient with mast-cell leukemia (MCL), all classified according to WHO criteria ${ }^{3}$ (Table 1). We did not stain for P-S-Akt in ASM and MCL due to a lack of material. A most intriguing finding was that both P-Y-Stat5 and P-S-Akt could be localized predominantly to the cytoplasmic compartment of neoplastic MCs in all mastocytosis patients. 

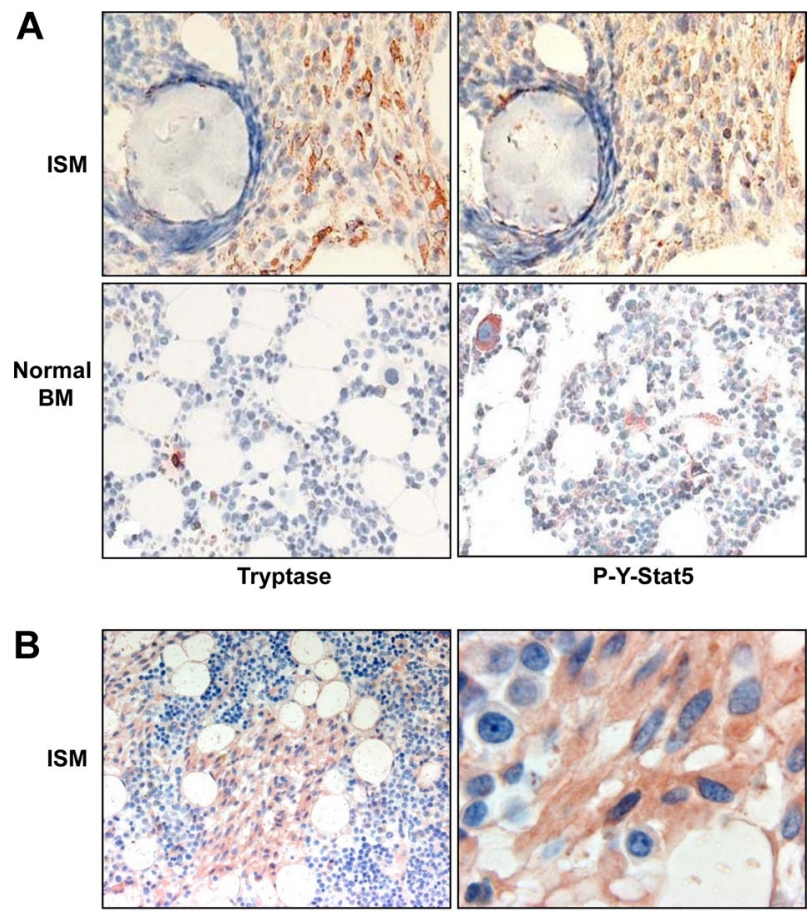

P-S-Akt

Figure 3. Immunohistochemical detection of P-Y-Stat5 and P-S-Akt in neoplastic human mast cells. (A) Adjacent bone marrow (BM) sections from a patient with indolent systemic mastocytosis (ISM) and normal bone marrow (normal BM) sections were stained with an antibody against tryptase for $\mathrm{MC}$ detection (brownish staining) and an antibody against P-Y-Stat5 (brownish staining). (B) Similarly, bone marrow sections from a patient with indolent systemic mastocytosis were stained with an antibody against P-Ser ${ }^{473}$-Akt antibody. Higher magnification of the immunostaining $(\times 400)$ is also shown.

\section{Cytoplasmic localization of P-Y-Stat5 and P-S-Akt in neoplastic MCs}

We next extended our analysis to isolated neoplastic MCs from a patient with MCL. The human MCL cell line HMC-1 is known to display the oncogenic Kit mutant D816V. ${ }^{43}$ Both types of malignant MCs expressed P-Y-Stat5 and P-S-Akt in these staining experiments (Figure 4A-C). The specificity of the immunostainings could be confirmed by using blocking phosphopeptides and by Western blot analysis (Figure 4B, Figure S6). Confirming our immunohistochemical staining results, P-YStat5 was primarily detected in the cytoplasm of leukemic MCs although a significant fraction of P-Y-Stat5 was also found in the nucleus of HMC-1 cells. Next, cell fractionation experiments were made to better quantify and analyze nuclear versus cytoplasmic P-Y-Stat5. Only a minor fraction colocalized to the nucleus, whereas cytoplasmic P-Y-Stat5a and P-Y-Stat5b were much more abundant (Figure 4D,E). Cell fractionation was controlled by cytoplasmic Raf-1 and nuclear Topoisomerase-I. Nuclear P-Y-Stat5 proteins remain transcriptionally active and contribute to growth of HMC-1 cells (Figure S5). Finally, we were able to show by flow cytometry that persistent activation of Stat5 in HMC-1 cells is dependent on KitD816V TK activity since PKC412, a Kit TK inhibitor, abrogated the expression of phosphorylated Stat5 in these neoplastic MCs (Figure 4F). Collectively, these data suggest an important function of P-Y-Stat5 downstream of KitD816V in the cytoplasm of human neoplastic MCs, supporting our results with oncogenic mice that underwent transplantation with $\mathrm{cS} 5^{\mathrm{F}}$.

\section{Proliferation of neoplastic MCs requires activation of Stat5}

We next determined whether activation of Stat5 was necessary for the growth of neoplastic human MCs (HMC-1). For this purpose, we directly transduced recombinant Stat5 proteins fused to the protein transduction domain of the HIV TAT protein into MCs. We first aimed to analyze the effect on MC growth of TAT-Stat5 proteins. Three TAT-Stat5 fusion proteins (Figure 5A) were applied: the wild-type form (TAT-wtStat5a), a constitutively active Stat5 mutant (TAT-cS5 ${ }^{\mathrm{F}}$ ), and a Stat5 mutant that lacks the transactivation domain (TAT-dnStat5a). These Stat5 variants were generated and purified from bacterial extracts (Figure 5B). Transduction efficiency of the 3 different TAT-Stat5 proteins in HMC-1 cells was verified by Western blotting with anti-HA and anti-Stat5 antisera (Figure 5C). Efficient and equal transduction of the 3 proteins was observed. Their effect on growth of HMC-1 cells was determined. Cells were left untransfected or were transduced with the TAT-Stat5 fusion proteins for 9 days, and the number of living cells was then evaluated by trypan blue exclusion (Figure 5D). Transduction of TAT-dnStat5 proteins abolished the growth of HMC-1 cells in these experiments, whereas transduction of TAT$\mathrm{cS}^{\mathrm{F}}$ and TAT-Stat5 proteins slightly increased their proliferation (Figure 5D). To further substitute our findings we used knockdown of expression of Stat5 in HMC-1 cells. For that purpose we developed and used lentiviral vectors expressing Stat5 shRNA. HMC-1 cells were transduced with recombinant lentivirusexpressing Stat5 shRNA (or luciferase shRNA as control), and thereafter Stat5 expression and cell growth were determined. In these experiments we found that inhibition of Stat5 (Stat5a and Stat5b) expression completely blocked HMC-1 cell growth (Figure $5 \mathrm{E}, \mathrm{F})$. Taken together, these data provide evidence that growth of neoplastic MCs requires persistent Stat5 activity.

\section{c-Kit signaling promotes the growth of human hematopoietic progenitor cells and MC development through Stat5}

SCF-binding to the Kit receptor induced proliferation of human $\mathrm{CD} 4^{+}$cells and MC development. ${ }^{7-9,52}$ Furthermore, murine MC development and function are abrogated in stat $5 a / b^{\Delta N}$ mice. ${ }^{22}$ Little is known so far about the role of Stat5 in SCF-induced human MC development. We first determined whether SCF could activate Stat5 in human $\mathrm{CD} 34^{+}$cells. Phosphorylation and nuclear localization of Stat5 after binding of SCF to Kit was strong, as shown by both Western blot and immunocytochemistry analysis with an anti-P-Y-Stat5 antibody, confirming that SCF signals through Stat5 in human $\mathrm{CD}^{+} 4^{+}$cells (Figure 6A). Similar results were obtained with the SCF-dependent human MC line LAD-2 (Figure S4F). We then transduced human $\mathrm{CD} 34^{+}$cells with the different TAT-Stat5 fusion proteins to analyze the role of Stat5. Expression of the 3 TAT-Stat5 proteins in transduced $\mathrm{CD}_{3} 4^{+}$cells was detected 12 hours after addition to the cell cultures (Figure 6B). The levels of transduced TAT-Stat5 proteins were equivalent to endogenous Stat5 and remained stable for at least 48 hours (not shown). TAT-Stat5 proteins $(10 \mathrm{nM})$ were therefore added every 48 hours to the $\mathrm{CD} 34^{+}$cell cultures to evaluate their biologic activities (Figure 6C). In the absence of SCF, none of the fusion proteins were able to promote the growth of $\mathrm{CD} 34^{+}$cells (data not shown). In contrast, the numbers of $\mathrm{CD}_{34}{ }^{+}$cells transduced with the TAT-wtStat5a and TAT-cS5 ${ }^{\mathrm{F}}$ were significantly enhanced in the presence of SCF $(10 \mathrm{ng} / \mathrm{mL})$, whereas no growth promotion was seen with the TAT-dnStat5a-transduced cells. TAT-wtStat5a and TAT-cS5 ${ }^{\mathrm{F}}$ were similar in their ability to promote growth of $\mathrm{CD} 34^{+}$cells during the first 10 days of culture. However, after this period, we found a 
A

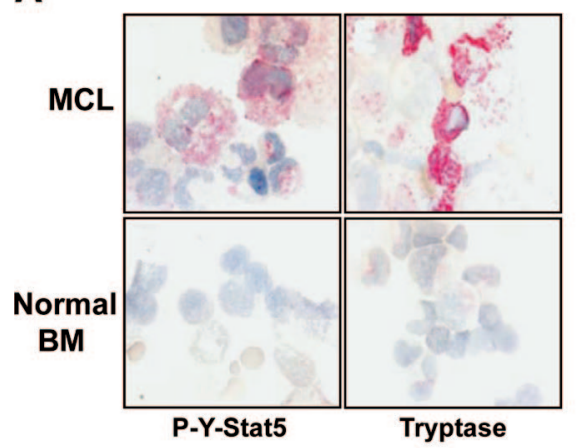

C

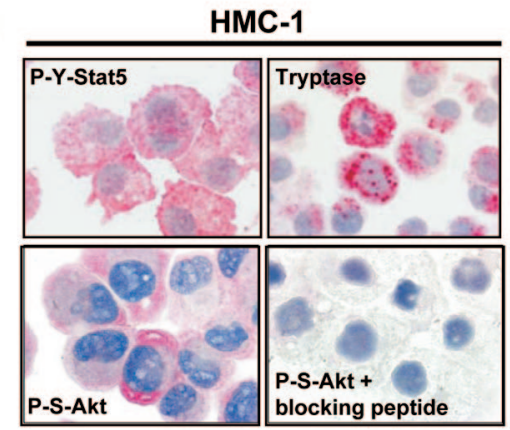

B

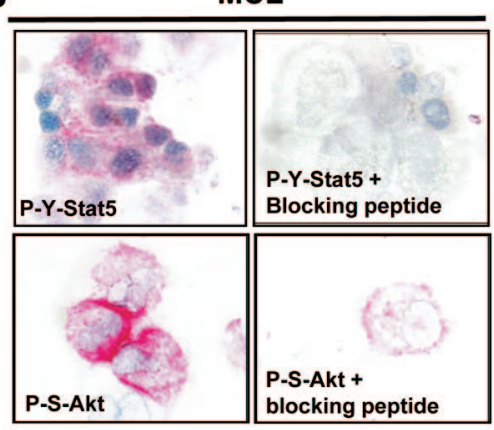

D

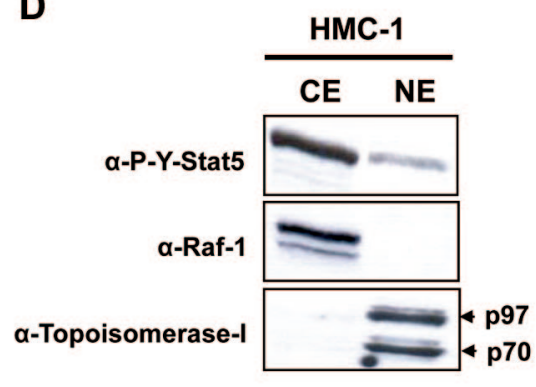

$\mathbf{F}$

E

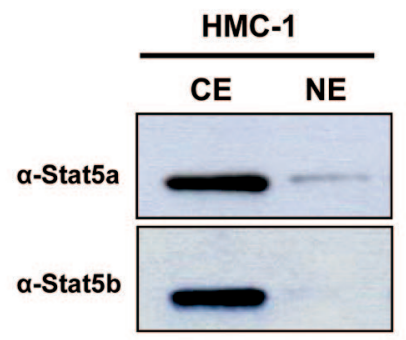

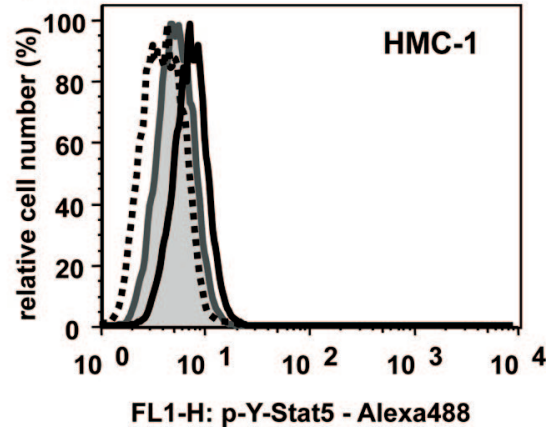

Figure 4. Detection and localization of P-Y-Stat5 and P-S-Akt in isolated neoplastic mast cells. (A) Expression of P-Y-Stat5 and tryptase was also evaluated by immunocytochemistry in isolated neoplastic MCs (from a patient with mast cell leukemia [MCL]) and normal isolated BM cells. (B) Detection of P-YStat5 and P-S-Akt in neoplastic MCs obtained from patients with MCL in the absence or presence of a blocking phospho-peptide. (C) Immunodetection of P-YStat5, P-S-Akt, and tryptase in the human HMC-1 neoplastic MC line. The P-S-Akt staining was also performed in the presence of a blocking phosphopeptide. (D,E) Cytoplasmic and nuclear extracts (CE and NE) were prepared from HMC-1 cells and analyzed by Western blotting using the indicated antibodies. (F) Detection of cytoplasmic P-Y-Stat5 in HMC-1 cells by FACS. Cells were cultured in control medium (solid line, open graph) or $1 \mu \mathrm{M}$ PKC412 (solid line, gray graph) at $37^{\circ} \mathrm{C}$ for 4 hours followed by FACS using an antibody against P-Y-Stat5. The dotted line represents the buffer control. The isotype control exhibited a slight shift compared with the buffer control, but did not change after exposure to PKC412 (not shown). Representatives of 3 independent experiments are shown. growth advantage of $\mathrm{CD} 4^{+}$cells transduced with TAT-cS5 ${ }^{\mathrm{F}}$ (Figure 6C). We were able to expand these transduced cells for at least 7 weeks in similar growth rates than obtained in 3-week cultures. In addition, the TAT-wtStat5a and the TAT-cS5 ${ }^{\mathrm{F}}$ fusion proteins were found to promote SCF-induced MC development as evidenced by expression of markers specific for the MC lineage, including tryptase and FceRI, the high affinity $\operatorname{IgE}$ receptor. Cell-surface expression of FceRI was determined by flow cytometry 30 days after transduction of TAT-wtStat5a or TAT-cS5 ${ }^{\text {F }}$ proteins in $\mathrm{CD}_{3} 4^{+}$cells grown in presence of SCF. We consistently found that transduction of TAT-wtStat5a or TAT-cS5 $5^{\mathrm{F}}$ proteins increased the percentage of cells expressing Fc $\in$ RI as compared with nontransduced cells ( $25.1 \%$ vs $11.9 \%$ of total cells; Figure $6 \mathrm{E})$. FceRI expression was approximately 2-fold elevated upon TAT-cS5 ${ }^{\mathrm{F}}$ transduction $(\sim 45 \%)$ compared with TAT-wtStat5a. Cells transduced with TAT-cS5 ${ }^{\mathrm{F}}$ show the presence of metochromatic granules after staining with toluidine blue. Immunocytochemical analysis with antitryptase antibody revealed that almost $80 \%$ of these cells were tryptase positive (Figure 6E). Overall, these data provide evidence that SCF-mediated expansion of human hematopoietic progenitors and $\mathrm{MC}$ development require $\mathrm{P}-\mathrm{Y}$-Stat5 activity.

\section{Stat5 associates with PI3K in human neoplastic MCs and regulates cell growth through Akt kinase}

Formation of a complex between Stat5 and PI3K, and the consecutive activation of Akt, apparently promotes neoplastic MC development in vitro and in vivo in mice that underwent transplantation with $\mathrm{cS}^{\mathrm{F}}$. We therefore determined whether such a complex would also be present in neoplastic HMC-1 cells. For this purpose, Stat5 was immunoprecipitated from HMC-1 cell extracts, and the presence of coimmunoprecipitated p85 was assessed by Western blot analysis (Figure 7A). Results from 2 different immunoprecipitation experiments demonstrated that $\mathrm{p} 85$ associated with Stat5 in these neoplastic MCs. The specificity of this interaction was confirmed by performing the reverse experiment and we were also able to show the presence of Stat5 in the p85 immunoprecipitates (Figure 7A right panel).

We recently reported the successful use of recombinant TATwtAkt (wild-type [wt]) and TAT-dnAkt (dominant-negative [dn]) proteins to demonstrate the crucial role of Akt in the transforming properties of constitutively active Stat5 proteins. ${ }^{42}$ Thus, we freshly purified these 2 recombinant proteins to analyze the requirement of Akt in the proliferation of HMC-1 cells. In particular, cells were 
Figure 5. Biologic effects of Stat5 proteins on neoplastic mast cell growth. (A) Schematic representation of TAT-Stat5 proteins. DBD indicates DNA binding domain; SH2, Src-homology domain 2; TAD, transactivation domain. (B) Purity of recombinant TAT-Stat5 proteins was assessed by Coomassie blue staining on SDS-PAGE. L indicates bacterial lysate; E, eluate fraction. (C) HMC-1 cells were transduced with the different TAT-Stat5 proteins (10 $\mathrm{nM})$ during 24 hours. Lysates from transduced cS5 $\mathrm{F}$-BM cells were prepared and analyzed by Western blotting with the indicated antibodies. (D) HMC-1 cells were transduced or not with $10 \mathrm{nM}$ of the different TAT-Stat5 proteins during 9 days and the number of living cells was determined every 3 days using the trypan blue dye assay. Results are the mean of 3 independent experiments. (E) HMC-1 cells were transduced with recombinant lentiviruses expressing a Stat5 shRNA or a luciferase shRNA as control. GFP ${ }^{+}$cells were sorted by flow cytometry and cultured in normal medium for 9 days. Cell extracts were then prepared and analyzed by Western blot with indicated antibodies. (F) The number of viable $\mathrm{GFP}^{+}$ cells expressing Stat 5 or luciferase shRNAs was also enumerated every 3 days. Representatives of 2 independent experiments are shown.
A

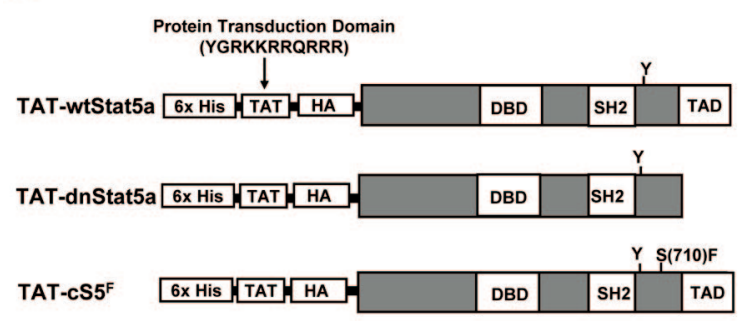

B

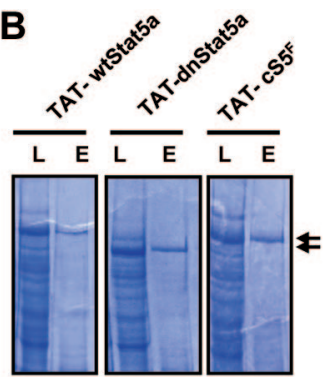

C

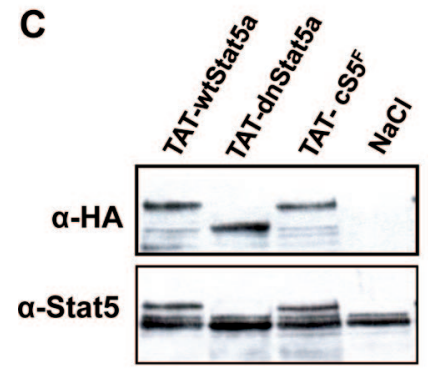

E

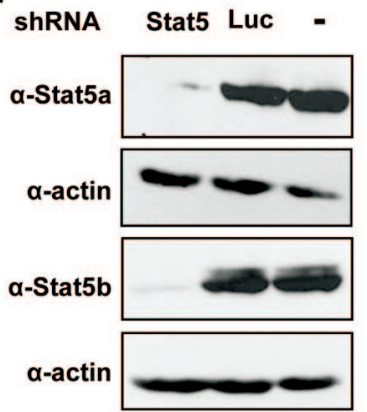

D

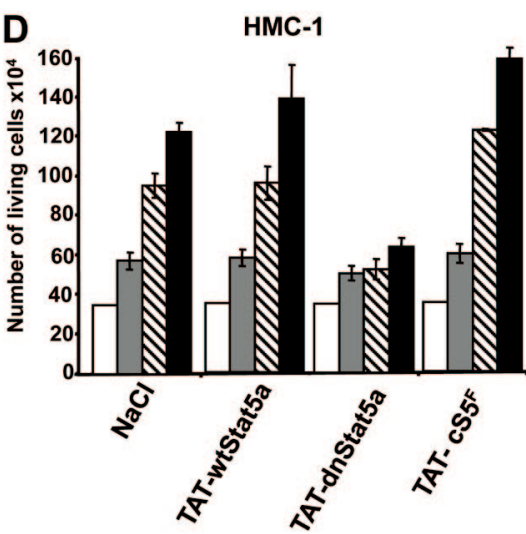

F

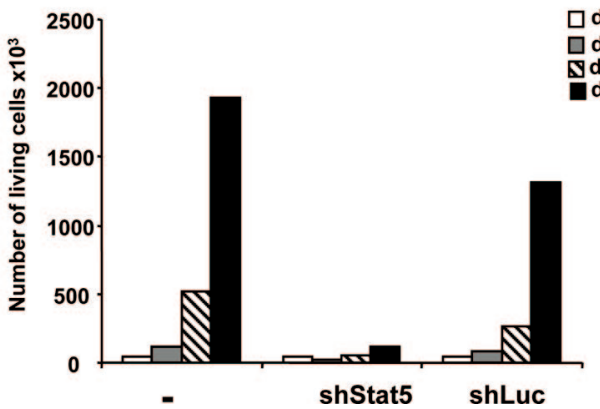

incubated with TAT-wtAkt or TAT-dnAkt proteins $(100 \mathrm{nM})$ for 3, 6 , or 9 days, and then cell growth was determined. Transduction of TAT-dnAkt inhibited the proliferation of HMC-1 cells whereas TAT-wtAkt was without any detectable effects (Figure 7B). In control Western blot experiments with anti-HA and anti-Akt antibodies, we showed that both TAT-Akt fusion proteins were efficiently transduced into HMC-1 cells (Figure 7C). We next analyzed whether inhibition of both Stat5 and Akt activities could synergistically increase the growth inhibitory response in neoplastic MCs. In these experiments, HMC-1 cells were incubated with recombinant TAT-Stat5 (wt or dn), TAT-Akt (wt or dn) proteins, or a mixture of both proteins before determining cell growth (Figure 7D). Results showed that transduction of TAT-dnStat5 or TATdnAkt alone inhibited HMC-1 cell growth, but addition of both proteins did not further increase the growth inhibitory effect. Similar results were obtained by incubating HMC-1 cells with the PI3K inhibitor LY294002 and the TAT-dnStat5 protein (data not shown). We next determined the effect of transduced TAT-dnStat5 or TAT-cS5 $5^{\mathrm{F}}$ on the levels of phosphorylated Akt in HMC-1 cells. We found that whereas TAT-cS5 $5^{\mathrm{F}}$ increases Akt phosphorylation, transduction of TAT-dnStat5 in HMC-1 cells inhibited Akt phosphorylation, indicating that Stat5 regulates Akt activity in HMC-1 cells. These data were also confirmed through the use of pharmacologic inhibitors. In fact, addition of LY294002 did not result in decreased Stat 5 activation. As expected and in line with our data above, Akt phosphorylation was abrogated when using an inhibitor of Stat5 activation (Figure S6). Collectively, these data indicate that constitutive activation of Stat5 and Akt are interconnected to promote MC growth via a shared signaling pathway triggered by oncogenic Kit receptors.

\section{Discussion}

Activating mutations of tyrosine kinases are often associated with the development of hematologic malignancies. For instance, Bcr$\mathrm{Abl}$ and point mutations in Jak2 kinase (Jak2V617F) or in c-Kit (KitD816V) are responsible for myeloproliferative and MC proliferative disorders. These oncogenic tyrosine kinases activate distinct signaling pathways that play a role in cell growth and survival. ${ }^{28,29,33-35}$ Activation of the PI3K/Akt pathway and Stat5 are commonly induced by these oncogenes, and their constitutive activation may be sufficient to transform hematopoietic cells. Here, we demonstrate that persistent activation of Stat5 and Akt in bone marrow cells of $\mathrm{cS}^{\mathrm{F}}$ mice results in an increased growth of MCs in vivo and enhanced Kit-dependent development of MCs in vitro. 
A

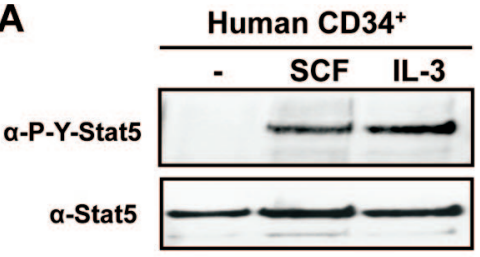

B

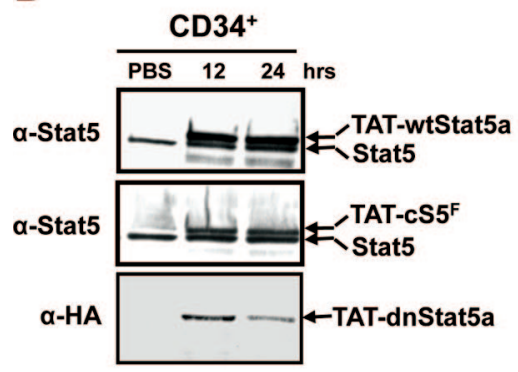

D

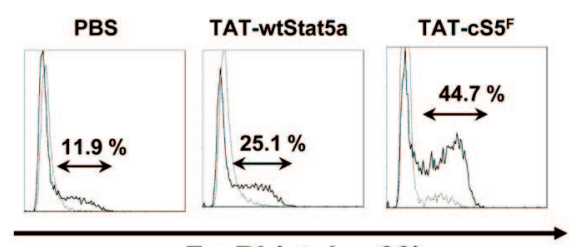

FcERI (at day 30)

C
Human CD34+

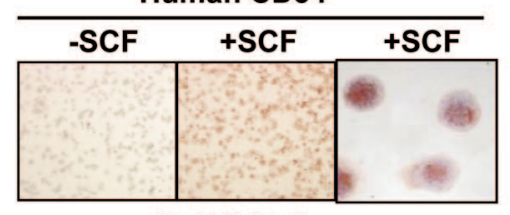

IC: P-Y-Stat5

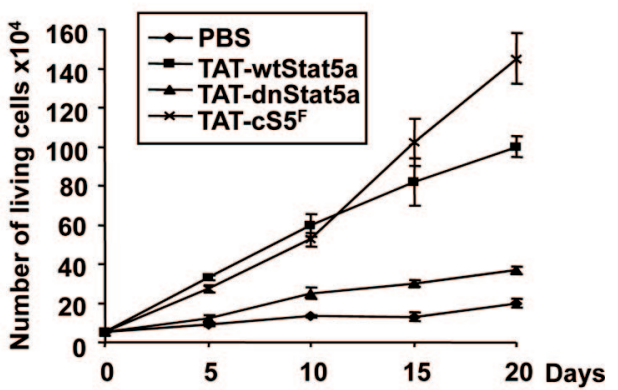

E $\quad \mathrm{CD}^{2} 4^{+}+\mathrm{TAT}-\mathrm{CS} 5 \mathrm{~F}$ (30 days)

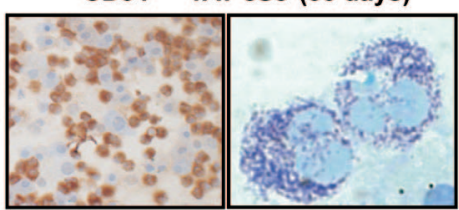

IC: Anti-tryptase Toluidine Blue
Figure 6. Analysis of Stat5 function in human $\mathrm{CD}^{2}{ }^{+}$cells via c-Kit signaling. (A) Purified human $\mathrm{CD} 34^{+}$cells from umbilical cord blood were stimulated with recombinant SCF $(10 \mathrm{ng} / \mathrm{mL})$ or IL-3 $(10 \mathrm{ng} / \mathrm{mL})$ for 30 minutes. Tyrosine phosphorylation of Stat5 was evaluated by Western blot analysis using an anti-P-YStat5 antibody. SCF-mediated activation of Stat5 in $\mathrm{CD}^{+} 4^{+}$cells was also analyzed by immunocytochemistry with an anti-P-Y-Stat5 (AX1) antibody. (B) Human $\mathrm{CD}_{4}{ }^{+}$cells were transduced or not (PBS) with the different TAT-Stat5 proteins $(10 \mathrm{nM})$ for the indicated times. After extensive washes, the presence of recombinant TAT-Stat5 proteins in $\mathrm{CD} 34^{+}$cells were analyzed by Western blotting with the indicated antibodies. (C) $\mathrm{CD}_{3}{ }^{+}$cells $\left(50 \times 10^{3} ; \mathrm{n}=4\right)$ were cultured in the presence of SCF $(10 \mathrm{ng} / \mathrm{mL})$ for 20 days. TAT-Stat5 proteins $(10 \mathrm{nM})$ were added or left away (PBS) every 2 days in culture and cells were enumerated every 5 days. (D) Transduced cells grown for 30 days in the presence of SCF were analyzed for expression of $\mathrm{Fc} \in \mathrm{R} 1$ by flow cytometry. Immunocytochemical analysis (IC) was also performed on TAT-CS5 $5^{\mathrm{F}}$ proteintransduced cells with an antitryptase antibody. (E) The presence of metachromatic granules was detected after staining with toluidine blue. Results shown are representative of 4 independent experiments.
Most importantly, we provide evidence that constitutive activation of Stat5 and Akt are detectable in neoplastic MCs in patients suffering from systemic mastocytosis and MCL. We also show that P-Y-Stat5 and P-S-Akt proteins promote MC growth, suggesting that persistent Stat5 and Akt activation has an important role in mastocytosis. This observation was supported by our finding that abrogation of Stat5 or Akt activity is followed by inhibition of growth of neoplastic MCs expressing the oncogenic KitD816V mutant.

We have recently shown that activated Stat5 is primarily located in the cytoplasm of leukemic cells in myeloid leukemias. ${ }^{42}$ In the present study, we confirmed these findings also to neoplastic MCs of mice and men. These findings suggest that besides its nuclear function as a transcription factor, the highly expressed and tyrosine-phosphorylated Stat5 might also have an important role as an effector or signaling adaptor in the cytoplasm to amplify (eg, Kit-dependent) oncogenic signaling. In fact, based on our results, we hypothesize that cytoplasmic Stat5, and the Stat5/PI3K complex with consecutive activation of Akt, play important roles in malignant growth of MCs. P-Y-Stat5 interacted with the cytoplasmic scaffolding adapter Gab2 in HMC-1 cells and expression of a Gab2 mutant deficient in PI3K binding inhibited HMC-1 cell growth (Figure S7). Our data from neoplastic MCs are in line with data from myeloid leukemias, where we found that phosphorylated Stat5 proteins form a signaling complex with the p85 regulatory subunit and Gab2. ${ }^{41,42}$ Thus, Stat5, Gab2, and PI3K/Akt may act in concert via a common (Kit-dependent) oncogenic signaling pathway in neoplastic MCs. The essential role for Stat5, Gab2, and PI3K expression in $\mathrm{MC}$ development and function came from knockout mouse analysis. ${ }^{20-24,53,54}$ Interestingly, mice deficient in p85 or Gab2 have a profound defect in gastrointestinal MCs, while development of MCs in other tissues remained unaffected. ${ }^{20}$ These data are consistent with our observations that $\mathrm{cS}^{\mathrm{F}}$ induced PI3K activation (via formation of a Stat5/Gab2/p85 signaling complex) promotes in particular the development of gastrointestinal MCs.

In contrast to our data, it was recently shown that neoplastic $\mathrm{MCs}$ in systemic mastocytosis display nuclear P-Y-Stat5 ${ }^{47}$ On the other hand, we and others have shown that cytoplasmic P-Y-Stat5 can be detected in the cytoplasmic compartment in AML. ${ }^{42,55}$ The reason for the discrepancy concerning nuclear as opposed to cytoplasmic P-Y-Stat5 detection in neoplastic MCs remains unknown. One reason may be the differences in the staining protocols applied. In fact, depending on the technique applied, the nuclear or the cytoplasmic portion of P-Y-Stat5 may be optimally visualized. This would also be in line with the hypothesis that P-Y-Stat5 in neoplastic (mast) cells can fulfill important functions in both the cell nucleus and the cytoplasm. Based on our data in HMC-1 cells, an attractive hypothesis would be that both the DNA-binding and $\mathrm{PI} 3 \mathrm{~K} /$ Akt-triggering activities contribute to the oncogenic potential of Stat5. Irrespective, our data suggest that KitD816V signals via P-Y-Stat5 in neoplastic MCs. It is questionable if Stat5 is also an important signaling effector in further diseases associated with oncogenic Kit mutations like in gastrointestinal stromal tumors (GISTs) or acute myeloid leukemias.

Despite the important role of MCs in immunity, allergic response, or inflammatory diseases models in mice, signaling properties of human MCs or signaling effectors that are involved in human MC development are still poorly understood. It was therefore important to demonstrate here that activation and tyrosine phosphorylation of Stat5 after SCF binding to c-Kit is required to promote expansion of human hematopoietic progenitors and consecutive MC development. It was previously shown that human 
Figure 7. P-Y-Stat5 interacts with PI3-kinase in HMC-1 cells. (A) Stat5 (left panel) or p85 (right panel) was immunoprecipitated from $\mathrm{HMC}-1$ cell extracts with specific or isotype control antibodies. The presence of p85 (left panel) or Stat5 (right panel) in the immunoprecipitates was detected by Western blot. (B) HMC-1 cells were also transduced with $100 \mathrm{nM}$ TAT-wtAkt or TAT-dnAkt for 9 days and the number of living cells was determined every 3 days using the trypan blue dye assay. Results are the mean of 3 independent experiments. (C) Lysates from transduced HMC-1 cells were analyzed by Western blotting using anti-HA and antiAkt antibodies. (D) HMC-1 cells were transduced or not $(\mathrm{NaCl})$ with the TAT-wtStat5, TAT-dnStat5, TAT-wtAkt, and TAT-dnAkt fusion proteins or a mixture of TATwtStat5/TAT-wtAkt or TAT-dnStat5/TAT-dnAkt proteins (ratio 1:1) for 3 days. Cell growth was determined using the trypan blue dye assay. (E) Extracts from HMC-1 cells, either untreated $(\mathrm{NaCl})$ or transduced with TAT$\mathrm{CS}^{\mathrm{F}}$ and TAT-dnStat5 recombinant proteins for 6 days, were analyzed by Western blot with anti-P-S-Akt and anti-Akt antibodies. Representatives of 3 independent experiments are shown.
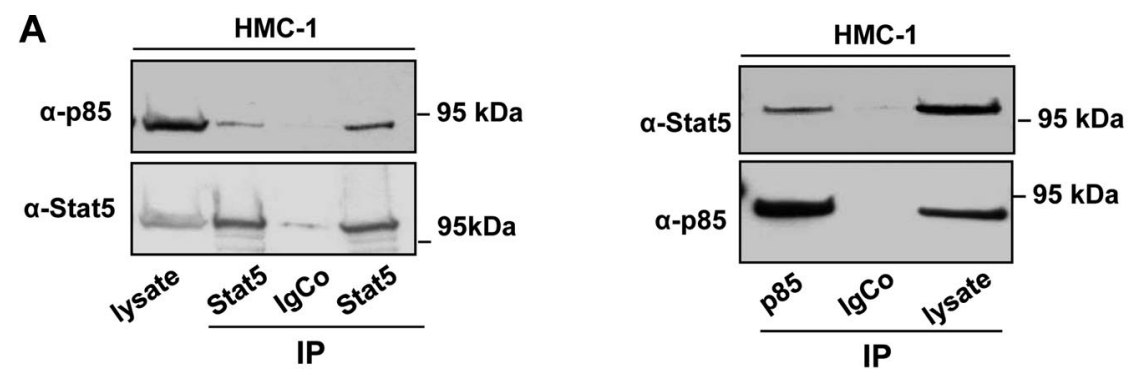

B

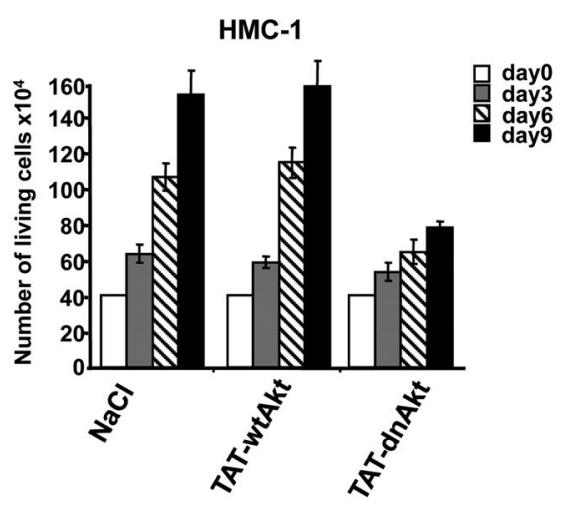

C
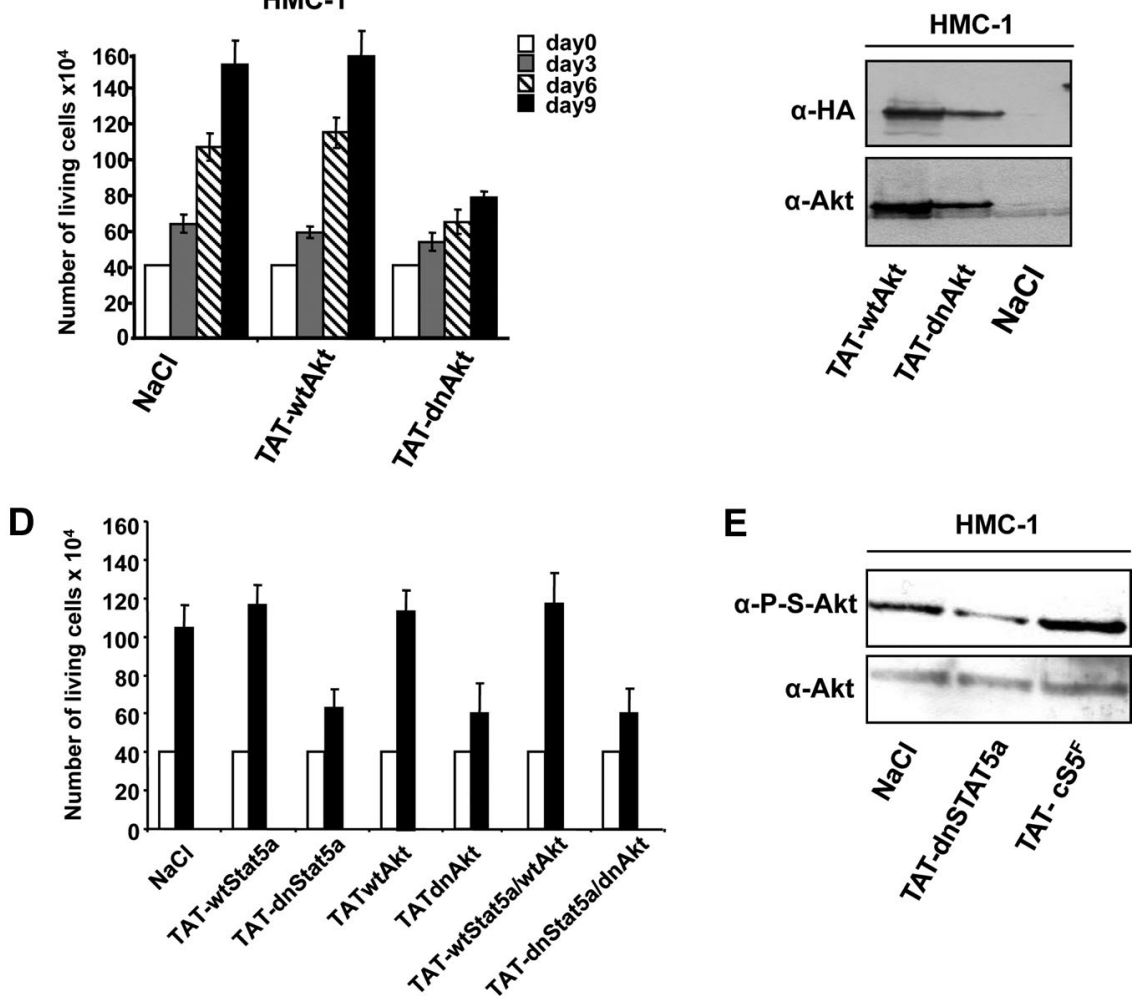

MCs arise from a pluripotent $\mathrm{CD} 34^{+}$progenitor cell population that also give rise to eosinophils, basophils, Monocytes, and neutrophils. ${ }^{7,9,56}$ Thus it is conceivable that the growth-promoting effect of the TAT-Stat5 proteins on $\mathrm{CD} 34^{+}$cells affects the entire cell population. Importantly, our data also suggest that deregulated Stat5 activity due to oncogenic c-Kit signaling promotes neoplastic cell development in part through an uncontrolled mitogenic effect on hematopoietic stem cells (HSCs). This idea is also supported by recent work demonstrating a critical role of Stat5 in HSC selfrenewal and/or expansion in mammals. ${ }^{57-59}$

The activation of Stat5 in myeloid diseases and MC neoplasms suggests that small inhibitor molecules targeting Stat5 or Akt might be relevant for the treatment of patients suffering from these malignancies. Such novel targeted drugs may be of special interest for those cases that are resistant against conventional kinase inhibitors, which have been described in patients with CML but also in patients with mastocytosis. ${ }^{60-62}$ In fact, although new Kit-targeting drugs have been described to counteract growth of neoplastic MCs in most patients, ${ }^{33,63,64}$ resistance may develop within a short time. ${ }^{62,65}$ Therefore, drugs targeting the Stat5-Akt axis are an alternative and complementary strategy in the treatment of systemic mastocytosis.

\section{Acknowledgments}

We thank Catherine Poupart and the nursing staff of the delivery unit from Center Hospitalier Universitaire Amiens for the collection of umbilical cord blood samples, Aline Regnier and Sylvie Vermersh for excellent technical assistance, and Dr Ulrich Blank (Institut Pasteur) for the murine IgE antibody.

This study was supported by Association de la Recherche contre le Cancer (ARC), Ligue contre le Cancer (Comité du Nord/Pas de Calais/Picardie), Conseil Régional de Picardie, Fondation de France, Fonds zur Förderung der Wissenschaftlichen Forschung in Österreich (FWF; grant P17205-B14 to P.V. and grant SFB F28 to R.M.), and Cent pour Sang la Vie. N.H. was supported by the French and Algerian Ministry for Research and Technology and ARC.

\section{Authorship}

Contribution: N.H., C.B., K.F., K.S., R.K., S.M.-L., L.K., M.K., and S.Y. designed and performed research; V.G.-G., J.G., L.B., and 
I.D.-F. contributed analytical tools and analyzed data; K.L. analyzed data and wrote the paper; and P.V., R.M., and F.G. designed research, analyzed data, and wrote the paper.

Conflict-of-interest disclosure: The authors declare no competing financial interests.
Correspondence: F. Gouilleux, Inserm E351, Faculté de Médecine, 3 rue des Louvels, 80036 Amiens, France; e-mail: fabrice.gouilleux@sa.u-picardie.fr; or R. Moriggl, Ludwig Boltzmann Institute for Cancer Research, Währinger Str 13a A-1090 Vienna, Austria; e-mail: richard.moriggl@lbicr.lbg.ac.at.

\section{References}

1. Austen KF, Boyce JA. Mast cell lineage development and phenotypic regulation. Leuk Res. 2001; 25:511-518.

2. Galli SJ, Nakae S, Tsai M. Mast cells in the development of adaptive immune responses. Nat Immunol. 2005;6:135-142.

3. Valent P, Horny HP, Escribano L, et al. Diagnostic criteria and classification of mastocytosis: a consensus proposal. Leuk Res. 2001;25:603-625.

4. Valent $P$, Akin $C$, Sperr WR, et al. Diagnosis and treatment of systemic mastocytosis: state of the art. Br J Haematol. 2003;122:695-717.

5. Akin C, Metcalfe DD. Systemic mastocytosis. Annu Rev Med. 2004;55:419-432.

6. Valent P, Akin C, Escribano L, et al. Standards and standardization in mastocytosis: consensus statements on diagnostics, treatment recommendations and response criteria. Eur J Clin Invest. 2007;37:435-453.

7. Kitamura Y, Yokoyama M, Matsuda H, Ohno T, Mori KJ. Spleen colony-forming cell as common precursor for tissue mast cells and granulocytes. Nature. 1981:291:159-160.

8. Kirshenbaum AS, Kessler SW, Goff JP, Metcalfe DD. Demonstration of the origin of human mast cells from CD34+ bone marrow progenitor cells. J Immunol. 1991;146:1410-1415.

9. Agis $\mathrm{H}$, Willheim M, Sperr WR, et al. Monocytes do not make mast cells when cultured in the presence of SCF. Characterization of the circulating mast cell progenitor as a c-kit ${ }^{+}, \mathrm{CD}_{3} 4^{+}, \mathrm{Ly}^{-}$, $\mathrm{CD}_{14}^{-}, \mathrm{CD}^{-} 7^{-}$, colony-forming cell. J Immunol. 1993; 151:4221-4227.

10. Kitamura Y, Go S, Hatanaka K. Decrease of mast cells in W/Wv mice and their increase by bone marrow transplantation. Blood. 1978;52:447-452.

11. Kitamura $Y$, Go S. Decreased production of mast cells in S1/S1d anemic mice. Blood. 1979;53: 492-497.

12. Geissler EN, Ryan MA, Housman DE. The dominant-white spotting (W) locus of the mouse encodes the c-kit proto-oncogene. Cell. 1988;55: 185-192.

13. Huang EJ, Manova K, Packer Al, Sanchez S, Bachvarova RF, Besmer P. The haematopoietic growth factor $\mathrm{KL}$ is encoded by the $\mathrm{SI}$ locus and is the ligand of the c-kit receptor, the gene product of the W locus. Cell. 1990;63:225-233.

14. Nagata $\mathrm{H}$, Worobec AS, Oh CK, et al. Identification of a point mutation in the catalytic domain of the protooncogene c-kit in peripheral blood mononuclear cells of patients who have mastocytosis with an associated hematologic disorder. Proc Natl Acad Sci U S A. 1995;92:10560-10564.

15. Longley BJ, Tyrrell L, Lu SZ, et al. Somatic c-KIT activating mutation in urticaria pigmentosa and aggressive mastocytosis: establishment of clonality in a human mast cell neoplasm. Nat Genet. 1996;12:312-314.

16. Zappulla JP, Dubreuil P, Desbois S, et al. Mastocytosis in mice expressing human Kit receptor with the activating Asp816Val mutation. J Exp Med. 2005;202:1635-1641.

17. Ryan JJ, Huang H, McReynolds LJ, et al. Stem cell factor activates STAT-5 DNA binding in IL-3derived bone marrow mast cells. Exp Hematol. 1997;25:357-362

18. Taylor ML, Metcalfe DD. Kit signal transduction. Hematol Oncol Clin North Am. 2000;14:517-535.

19. Roskoski R Jr. Signaling by Kit protein-tyrosine kinase: the stem cell factor receptor. Biochem Biophys Res Commun. 2005;337:1-13

20. Fukao T, Yamada T, Tanabe M, et al. Selective loss of gastrointestinal mast cells and impaired immunity in PI3K-deficient mice. Nat Immunol. 2002;3:295-304

21. Nishida K, Wang L, Morii E, et al. Requirement of Gab2 for mast cell development and KitL/ signaling. Blood. 2002;99:1868-1869.

22. Shelburne CP, McCoy ME, Piekorz R, et al. Stat5 expression is critical for mast cell development and survival. Blood. 2003;102:1290-1297.

23. Gu H, Saito K, Klaman LD, et al. Essential role for Gab2 in the allergic response. Nature. 2001;412: 186-190.

24. Barnstein BO, Li G, Wang Z, et al. Stat5 expression is required for lgE-mediated mast cell function. J Immunol. 2006;177:3421-3426.

25. Benekli M, Baer MR, Baumann H, Wetzler M. Signal transducer and activator of transcription proteins in leukemias. Blood. 2003;101:29402954.

26. Vivanco I, Sawyers CL. The phosphatidylinositol 3-Kinase AKT pathway in human cancer. Nat Rev Cancer. 2002;2:489-501.

27. Lacronique V, Boureux A, Monni R, et al. Transforming properties of chimeric TEL-JAK proteins in $\mathrm{Ba} / \mathrm{F} 3$ cells. Blood. 2000;95:2076-2083.

28. Skorski T, Bellacosa A, Nieborowska-Skorska M, et al. Transformation of hematopoietic cells by $\mathrm{BCR} / \mathrm{ABL}$ requires activation of a PI3-K/Aktdependent pathway. EMBO J. 1997;16:6151 6161.

29. Carlesso N, Frank DA, Griffin JD. Tyrosyl phosphorylation and DNA binding activity of signal transducers and activators of transcription (STAT) proteins in hematopoietic cell lines transformed by Bcr/Abl. J Exp Med. 1996;183:811-820.

30. Nguyen MH, Ho JM, Beattie BK, Barber DL.TELJAK2 mediates constitutive activation of the phosphatidylinositol 3'-kinase/protein kinase B signaling pathway. J Biol Chem. 2001;276:32704 32713.

31. Sternberg DW, Tomasson MH, Carroll M, et al. The TEL/PDGFbetaR fusion in chronic myelomonocytic leukemia signals through STAT5 dependent and STAT5-independent pathways. Blood. 2001;98:3390-3397.

32. Mizuki M, Fenski R, Halfter H. Flt3 mutations from patients with acute myeloid leukemia induce transformation of 32D cells mediated by the Ras and STAT5 pathways. Blood. 2000;96:39073914.

33. Growney JD, Clark JJ, Adelsperger J, et al. Activation mutations of human c-KIT resistant to imatinib are sensitive to the tyrosine kinase inhibitor PKC412. Blood. 2005;106:721-724.

34. Levine RL, Wadleigh M, Cools J, et al. Activating mutation in the tyrosine kinase JAK2 in polycythemia vera, essential thrombocythemia, and myeloid metaplasia with myelofibrosis. Cancer Cell. 2005:7:387-397.

35. Chian R, Young S, Danilkovitch-Miagkova A, et al. Phosphatidylinositol 3 kinase contributes to the transformation of hematopoietic cells by the D816V mutant. Blood. 2001;98:1365-1373.

36. Schwaller J, Parganas E, Wang D, et al. Stat5 is essential for the myelo- and lympho-proliferative disease induced by TEL/JAK2. Mol Cell. 2000;6: 693-704.
37. Hoelbl A, Kovacic B, Kerenyi MA, et al. Clarifying the role of Stat5 in lymphoid development and Abelson induced transformation. Blood. 2006; 107:4898-4906

38. Ye D, Wolff N, Zhang S, Ilaria RL Jr. STAT5 signaling is required for the efficient induction and maintenance of CML in mice. Blood. 2006;107: 4917-4925.

39. Sattler M, Mohi MG, Pride YB, et al. Role for Gab2 in transformation by BCR/ABL. Cancer Cell. 2002;1:479-492.

40. Moriggl R, Sexl V, Kenner L, et al. Stat5 tetrame association is associated with leukemogenesis. Cancer Cell. 2005;7:87-99.

41. Nyga $R$, Pecquet $\mathrm{C}$, Harir $\mathrm{N}$, et al. Activated STAT5 proteins induce activation of the PI 3-kinase/Akt and Ras/MAPK pathways via the Gab2 scaffolding adapter. Biochem J. 2005;390: 359-366.

42. Harir N, Pecquet C, Kerenyi M, et al. Constitutive activation of Stat5 promotes its cytoplasmic localization and association with PI3-kinase in myeloid leukemias. Blood. 2007;109:1678-1686.

43. Butterfield JH, Weiler D, Dewald G, Gleich GJ. Establishment of an immature mast cell line from a patient with mast cell leukemia. Leukemia Res. 1988;12:345-355.

44. Sirven A, Ravet E, Charneau P, et al. Enhanced transgene expression in cord blood CD34(+)derived hematopoietic cells, including developing T cells and NOD/SCID mouse repopulating cells, after transduction with modified trip lentiviral vectors. Mol Ther. 2001;4:438-448.

45. Hsu SM, Raine L, Fanger H. Use of avidin-biotinperoxidase complex $(A B C)$ in immunoperoxidase techniques: a comparison between $\mathrm{ABC}$ and unlabeled antibody (PAP) procedures. J Histochem Cytochem. 1981;29:577-580.

46. Jordan JH, Walchshofer S, Jurecka W, et al. Immunohistochemical properties of bone marrow mast cells in systemic mastocytosis: evidence for expression of CD2, CD117/Kit, and bcl-x(L). Hum Pathol. 2001;32:545-552.

47. Zuluaga Toro T, Hsieh FH, Bodo J, Dong HY, Hsi ED. Detection of phospho-STAT5 in mast cells: a reliable phenotypic marker of systemic mast cell disease that reflects constitutive tyrosine kinase activation. Br J Haematol. 2007;139:31-40.

48. Galli SJ, Maurer M, Lantz CS. Mast cells as sentinels of innate immunity. Curr Opin Immunol. 1999;11:53-59.

49. Mekori YA, Oh CK, Metcalfe DD. IL-3-dependent murine mast cells undergo apoptosis on removal of IL-3: prevention of apoptosis by c-kit ligand. J Immunol. 1993;151:3775-3784.

50. Kohno M, Yamasaki S, Tybulewicz VL, Saito T. Rapid and large amount of autocrine IL-3 production is responsible for mast cell survival by lgE in the absence of antigen. Blood. 2005;105:20592065.

51. Metcalfe DD, Akin C. Mastocytosis: molecular mechanisms and clinical disease heterogeneity. Leukemia Res. 2001;25:577-582.

52. Valent $P$, Spanblöchl E, Sperr WR, et al. Induction of differentiation of human mast cells from bone marrow and peripheral blood mononuclear cells by recombinant human stem cell factor/kit-ligand in long-term culture. Blood. 1992;80:2237-2245.

53. Ikeda K, Nakajima $\mathrm{H}$, Suzuki K, Watanabe N, Kagami S, Iwamoto I. Stat5a is essential for the 
From www.bloodjournal.org at CNRS BiblioVie on March 12, 2009. For personal use only.

proliferation and survival of murine mast cells. Int Arch Allergy Immunol. 2005;137:45-50.

54. Fukao T, Terauchi Y, Kadowaki T, Koyasu S. Role of phosphoinositide 3-kinase signaling in mast cells: new insights from knockout mouse studies. J Mol Med. 2003;81:524-535.

55. Bunting KD, Xie XY, Warshawsky I, Hsi ED. Cytoplasmic localization of phosphorylated STAT5 in human acute myeloid leukemia is inversely correlated with Flt3-ITD. Blood. 2007;110:2775-2776.

56. Kirshenbaum AS, Goff JP, Semere T, Foster B, Scott LM, Metcalfe DD. Demonstration that human mast cells arise from a progenitor cell population that is $\mathrm{CD}_{34}{ }^{+}, \mathrm{c}-\mathrm{kit}^{+}$, and expresses aminopeptidase N(CD13). Blood. 1999;94:23332342

57. Bunting KD, Bradley HL, Hawley TS, Moriggl R, Sorrentino BP, Ihle JN. Reduced lymphomyeloid repopulating activity from adult bone marrow and fetal liver of mice lacking expression of STAT5. Blood. 2002;99:479-487.

58. Schuringa JJ, Chung KY, Morrone G, Moore MAS. Constitutive activation of STAT5A promotes human hematopoietic stem cell self-renewal and erythroid differentiation J Exp Med. 2004;200: 623-635.

59. Kato Y, Iwama A, Tadokoro $Y$, et al. Selective activation of STAT5 unveils its role in stem cell selfrenewal in normal and leukemic hematopoiesis. J Exp Med. 2005;202:169-179.

60. Ma Y, Zeng S, Metcalfe DD, et al. The c-KIT mutation causing human mastocytosis is resistant to STI571 and other KIT kinase inhibitors; kinases with enzymatic site mutations show different inhibitor sensitivity profiles than wild-type kinases and those with regulatory-type mutations. Blood. 2002;99:1741-1744.

61. Zermati Y, De Sepulveda P, Feger F, et al. Effect of tyrosine kinase inhibitor STI571 on the kinase activity of wild-type and various mutated c-kit receptors found in mast cell neoplasms. Oncogene. 2003;22:660-664.

62. Gorre ME, Mohammed M, Ellwood K, et al. Clinical resistance to STI-571 cancer therapy caused by BCR-ABL gene mutation or amplification. Science. 2001;293:876-880.

63. Gotlib J, Berube C, Growney JD, et al. Activity of the tyrosine kinase inhibitor PKC412 in a patient with mast cell leukemia with the D816V KIT mutation. Blood. 2005;106:2865-2870.

64. Gleixner KV, Mayerhofer M, Aichberger KJ, et al. PKC412 inhibits in vitro growth of neoplastic human mast cells expressing the D816V-mutated variant of KIT: comparison with AMN107, imatinib, and cladribine (2CdA) and evaluation of cooperative drug effects. Blood. 2006;107:752-759.

65. Gorre ME, Sawyers CL. Molecular mechanisms of resistance to STI571 in chronic myeloid leukemia. Curr Opin Hematol. 2002;9:303-307. 